\title{
Designing Democracy: The UTOPIA-Project and the Role of the Nordic Labor Movement in Technological Change during the 1970s and 1980s
}

\author{
Per Lundin \\ Div. of History of Science and Technology, KTH \\ 10044 Stockholm, Sweden \\ per. lundinaabe.kth.se
}

\begin{abstract}
By using the UTOPIA-project as an example, this paper highlights the role of the Nordic labor movement in technological change and underlines that there are different incentives for technological change. While corporations developing technology usually pursued increased efficiency in production, the UTOPIA-project aimed at other, alternative goals such as translating social values regarding job skills, quality of work, and quality of products into new computer hardware and software for the graphic industries. In the larger context, the UTOPIA-project can be seen as an attempt by the labor movement to revitalize and realize the old dream of industrial democracy by designing computing technology.
\end{abstract}

Keywords: Graphic industries, history of computing, industrial democracy, IT-history, labor movement, Sweden, trade unions, users.

\section{Introduction}

When the computer-based wave of rationalization hit industry, trade, business, and the public sector during the 1970s and the 1980s, many occupational groups feared they would lose control of their work and eventually their jobs. The "microelectronics revolution" during the mid-1970s transformed the job made by graphic workers [1, 2]. Many of them lost their jobs, and especially in the United States and Great Britain, extinction threatened the very existence of the occupation. In the Anglo-Saxon countries, the counter-strategies developed by organized labor were in general Ludditian, i.e. characterized by a resistance towards technological change [3-5].

This paper demonstrates that the responses articulated by the labor movement in the Nordic countries developed along a different path. The Nordic trade unions argued that if new technology could be developed on the premises of workers, it would be possible for them to keep their occupations. By investigating the conscious counterstrategies elaborated by Nordic trade unions and politically radical computer scientists during the 1970s and 1980s, this paper shows that they aimed to organize themselves with the help of technology rather than against technology. Particular attention will be paid to the UTOPIA-project and its attempts to develop computer hardware and software for the graphic industries. The important contextual elements discussed are 
the altering notions of technological change during the post-war period, the question and old dream of industrial democracy, the strong welfare states and long-lasting social democratic rule in the Nordic countries, and the belief in allegedly Nordic/Scandinavian values such as consensus, participation and democracy.

\section{The UTOPIA-Project}

The UTOPIA-project was a Nordic research project on trade union based development of, and training in, computer technology and work organization, especially text and image processing in the graphic industries. ${ }^{1}$ It occurred between 1981 and 1986. UTOPIA was an acronym in Swedish for training, technology, and products from a skilled worker's perspective, "Utbildning, teknik och produkt i arbetskvalitetsperspektiv." UTOPIA was conducted, in close cooperation with the Nordic Graphic Workers' Union (Nordisk Grafisk Union, NGU), at the Swedish Center for Working Life (Arbetslivscentrum, ALC), the Royal Institute of Technology in Stockholm, Sweden, and Aarhus University in Denmark. The project received the majority of its funding from the Swedish Center for Working Life and the National Board for Technical Development (Styrelsen för teknisk utveckling, STU) [6].

Two different social groups were brought together in the project: on the one hand, system designers, computer scientists, and work-efficiency experts; and on the other, activists and officials from unions representing some 120,000 printers, typographers, lithographers, and other skilled workers in the newspaper and printing industries of the five Nordic countries. The combination of politically radical scientists (which were influenced by the social movements of the late $1960 \mathrm{~s}$ as well as the radicalization of the universities the following decade) and graphic workers' unions (which, in comparison with other unions, were unusually intellectual, radical and technology-minded) was probably decisive for the outcome of the project. About fifteen people participated in the project. The Nordic Graphic Workers' Union appointed a group consisting of representatives from Denmark, Finland, Norway and Sweden who followed the project. At various stages the project cooperated with the Swedish state-owned publishing company and computer supplier Liber and its development project Text and Image Processing System (TIPS), the Swedish Social Democratic newspaper Aftonbladet, and the Danish independent center-leftist newspaper Information that was owned by its co-workers between 1970 and 1986 [6].

Obviously, UTOPIA developed in a very particular setting. State- or union-owned companies and cooperatively owned newspapers agreed either to support the project financially and ideologically or to participate as customers. Without this complex of government agencies, the realization of the project would probably not have occurred.

\section{Technology as Ideology}

The Norwegian mathematician and computer scientist Kristen Nygaard, who worked at the Norwegian Defense Research Agency (Forsvarets forskningsinstitutt) and later

${ }^{1}$ Yngve Sundblad presents the UTOPIA-project from an insider's perspective in the paper "UTOPIA: Participatory Design from Scandinavia to the World" (in this volume). 
at Norsk Regnesentral, inspired the researchers in the UTOPIA-project. Originally liberal in his views, he was influenced by the social movements of the 1960s and engaged himself politically to the left. His interests moved toward the social consequences of computerization. Together with Olav Terje Bergo, he cooperated in the early 1970s with the Norwegian Iron and Metal Workers' Union (Norsk Jern- og Metallarbeiderforbund, NJMF) on a project that dealt with planning, control, and data processing in enterprises from the perspectives of the employees [7]. Another important source of inspiration was Harry Braverman's seminal book from 1974 on the degradation of work, Labor and Monopoly Capital, which was translated into Swedish in 1977 [8, 9].

The NJMF-project received a couple of Nordic successors in the 1970s: the Danish DUE-project and the Swedish DEMOS-project. DEMOS, an acronym for Demokratisk styrning och planering (Democratic Control and Planning in Working Life) took place between 1975 and 1980, as a form of cooperation between the Swedish Center for Working Life and a number of trade unions. It dealt with planning, control and the use of computers from a wage-earner perspective, aiming to accumulate knowledge for the union movement [10].

Like its precursors, UTOPIA was an explicitly ideological project from the outset. The research program for the project from 1980 stated:

The experience gained by organized labor and the research conducted by trade unions during the 1970 s into the ability to influence new technology and the organization of work at local level highlighted a number of problems. One fundamental experience gained is that the "degrees of freedom" available to design the content and organization of work utilizes existing technology is often considerably less than that required to meet trade unions demands. Or expressed another way: Existing production technology more and more often constitutes an insurmountable barrier preventing the realization of trade union demands for the quality of work and a meaningful job [11, p. 255].

According to its participants, technology was an expression of the sort of society in which we live. It was value-laden - and the participants argued that existing technology and new technology largely reflected corporate interests instead of the interests of workers. Hence, it constrained the demands of workers and trade unions. In contrast to the trade unions' earlier "defensive strategies" for coping with technological change (e.g., reducing the negative effects of technology on employees by demanding reforms in legislation and concluding agreements), the participants in the UTOPIA-project worked with a "yet untried offensive strategy." The trade unions themselves were supposed to develop alternative technologies that mirrored the interests of trade unions rather than the ones of corporations:

The trade union movement itself draws up the technological and training alternatives and takes the sole responsibility for their implementation and development at local level [11, p. 256].

Thus, the aim with the UTOPIA-project was to help unions translate their social values regarding the job skills, quality of work, and quality of products into new 
computer hardware and software for the printing industry. Its participants held a strong belief that technology largely shaped working conditions. The underlying notion of technology being deterministic led them to argue that it was crucial for workers to develop and control alternative technologies.

\section{Altering Notions of Technological Change}

The concept of technological determinism ruled during the post-war period. However, as pointed out by David Edgerton, we should distinguish it from the notion of technology as autonomous - as out-of-control - an important theme in Western thought during the 1950s and the 1960s [12, 13]. Thus, the trade unions and the UTOPIA-project questioned the inevitability of technological change, not the technological determinism in social change per se. On the contrary, UTOPIA presupposed a 'soft' technological determinism [14, p. 2]. The point of departure for the project was that technology largely shapes the workers' conditions.

In the following, the paper will examine the governing Social Democrats' and the labor movement's approach to technology and technological change during the postwar period. Already in the Arbetarrörelsens efterkrigsprogram from 1944, a joint labor movement program set up by the Social Democrats and the Swedish Trade Union Confederation (Landsorganisationen i Sverige, LO), a growing technological optimism could be sensed. It was through technological progress that material and social welfare should be reached. The so-called Rigoletto conference organized by the Social Democrats in 1955, with participating scientists, technicians and politicians as well as representatives for trade and industry, received public attention. It resulted in the publication Tekniken och morgondagens samhälle (Technology and the Society of Tomorrow) and manifested an optimistic belief in technology and science [15]. This belief was established as a "supreme ideology," an ideology above all other ideologies, an ideology that unified all the existing political ideologies. It was also reflected in the discourse on the "death of ideologies" that took place in the Western world during the mid-1950s [16]. The notion of technological change as autonomous was strong. Thinking in the inevitability of technological progress, there was no need for considering alternative directions. There was only one way to go. The overall strategy was "total adaptation" to the demands of the assaulting technology. People understood that technology determined social change. Thus, both the belief that technology is autonomous and the belief that technology is largely deterministic in its character, existed side by side. Trade unions largely shared this approach. For example, the Trade Union Confederation adopted a "rationalization friendly approach," i.e., a strategy of adaptation towards technological change [17, p. 355].

In the aftermath of the "Boom Years" of the 1950s and the 1960s came the crisis of the 1970s. Technology changed from a promise to a threat. The rationalization that followed technological change did not produce prosperity to the same extent as before; instead, it increasingly made workers redundant and ultimately led to unemployment. A broad spectrum of political organizations and interest groups began to question the inevitability of technological change. It was almost as a discovery: technology is political! Instead of adapting ourselves to the inevitable technological progress, they argued, we should choose technology, thus choose our future; we should take control over technology in order to take control over work; etc. [18]. 
A very strong labor movement expanded its ambitions from wage negotiations into changing work organization and eventually technology [19]. For instance, the Trade Union Confederation established a Committee for Computing (LO:s dataråd) in 1976, the Workers' Educational Association (Arbetarnas Bildningsförbund, ABF); it conducted courses on the role of computers in social change; the Social Democratic Party presented an action program on computers and politics [20-25]. They moved in their own words - from a "defensive" to an "offensive" strategy. Instead of being the passive object of automation, they argued that the worker should be an active subject in shaping technological change.

Tage Erlander's Computer Symposium became an important political manifestation of this new posture. The symposium took place in 1980 at the Social Democratic residence Bommersvik and resulted in, among other things, the publication Datorerna och samhällsutvecklingen (Computers and the Development of Society). This labor movement summit conference consisted of participants such as the Social Democratic party secretary Sten Andersson (later Minister for Health and Social Affairs, and Foreign Minister), the president of the Swedish Confederation of Professional Employees (Tjänstemännens centralorganisation, TCO) Lennart Bodström (later Foreign Minister, and Minister for Education and Science), the member of the Social Democratic party executive Kjell-Olof Feldt (later Minister for Finance), the secretary for the Swedish Trade Union Confederation Rune Molin (later Minister for Industry), Hans Gustafsson (later Minister for Housing), Anders Ferm (managing director for the leading Social Democratic publishing house Tidens förlag) as well as the social democratic icons such as former Prime Minister Tage Erlander and former Minister for Finance Gunnar Sträng [26].

The well-known Finnish philosopher Georg Henrik von Wright opened the symposium with a reflection over Man, Technology, and the Future. He drew the attention to the profound social consequences of modern technology and thus addressed the overall themes of the conference: What social consequences does technological change have? Of special concern at the conference were the effects of technological change on employment. Given the profound consequences of technology: Who influenced and controlled technological change? Was it possible to control the progress of technology or was humanity forced to adapt itself to this development? Different visions and strategies for confronting technological change were suggested. The participants from trade unions, such as Rune Molin, emphasized that trade unions had to take command over technological change; another participant demanded "offensive decisions." In short: the employees needed to create their own alternatives [26].

Thus, during the 1970s it is possible to discern a shift in the notion of technological change from a belief that it was autonomous and out-of-control, towards a belief that it is controllable. However, the notion that technological change determined social change was as strong as before; it also was a very important incentive for the trade unions to take control over technological change. It is in this vein that we should understand the attempts of the Scandinavian labor movement to take control over work organization and technology and, consequently, projects such as NJMF, DEMOS, DUE, and above all, UTOPIA. 


\section{Industrial Democracy Reborn}

Henry Ford's assertion that "democracy stops at the factory gates" strikingly illustrates a problem that gained attention during the 1920 s in connection with the wave of democratization that swept through Europe after World War I. It dealt with the employees' influence in companies. After the seminal Saltsjöbaden agreement in 1938 between the Swedish Trade Union Confederation and the Swedish Employers' Confederation (Svenska arbetsgivareföreningen, SAF) the question gained renewed attention. The so-called Swedish Model was established during the 1930s and the 1940s and it became a role model manifesting technological optimism during the Boom Years of the 1950s and the 1960s [27, 28]. The social conflicts that arose at the end of the 1960s politized the industrial rationalization and the Swedish Model was questioned by the trade unions who protested against the "over-profits" made by corporations which they claimed did not sufficiently reach the employees. As a response, the powerful Social Democratic Party carried through a number of legislations during the 1970s that considerably strengthened the position of the employees in private companies. For instance, a law concerning the right of participation in decision-making, the Codetermination Act (Medbestämmandelagen, MBL) was legislated in 1976, and in the wake of these many reforms the question of industrial democracy called for attention once again [20]. Pelle Ehn, UTOPIA's project leader, rephrased Ford's assertion as, "democracy stops at the office door and the factory gate" [29].

The attempts to re-vitalize the question of industrial democracy had important parallels in other Scandinavian countries. Norway was pioneering with its program for industrial democracy during the 1960s and a number of experiments in work organization were completed. Similar attempts took place in Denmark, where several experiments in industrial democracy were conducted between 1969 and 1973. It should be noted that this trend is also discernible outside Scandinavia, and particularly in West Germany, which, among other things, carried through a similar Codetermination Act in 1976 [30, 31].

In conjunction with passing the Codetermination Act, the Swedish Parliament decided in June 1976 to establish a research institute with the purpose of bringing the research community and trade unions together. The Work Environment Fund

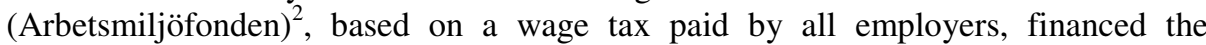
Swedish Center for Working Life [32]. One of the aims of the center was to "promote democracy in working life," and the concept of industrial democracy so to speak, was built in its regulations [33 p. 9, p. 13]. Furthermore, it edited (and financed) the international quarterly journal Economic and Industrial Democracy published by Sage Publications starting in 1980. The Center for Working Life carried out three big research projects dealing with trade unions and development of technology and organization: DEMOS (1975-1980), UTOPIA (1981-1986), and FRONT [34]. In the statutes of the Center for Working Life, it legislated that the research conducted should not consist of traditional reflective, analytic social science. Instead, it should take the form of "action research" where the "researcher's contribution as well as the reporting" should be "highly dependent on the actions of local parties" [33, p. 12].

\footnotetext{
${ }^{2}$ Former Occupational Safety Foundation (Arbetarskyddsfonden).
} 
The argument supported by the Center for Working Life was that trade unions needed to develop independently knowledge in order to shape technology and work organization actively. The center took a seminal role in the DEMOS and UTOPIA projects [33].

To conclude this section, the 1970s and the first half of the 1980s was a period when powerful trade unions made several attempts to realize the old dream of economic or industrial democracy. Through a number of governmental decisions, several new institutions with affinities to the labor movement such as the Work Environment Fund and the Center for Working Life took place on stage and quickly gained in strength. A state-supported complex giving voice to the demands of the labor movement was established and it became an important prerequisite for projects such as DEMOS and UTOPIA.

\section{Democracy by Design}

A "technology laboratory" where researchers and workers worked closely together was established at the Swedish Center for Working Life. The American Robert Howard reviewed UTOPIA for the MIT-based journal Technology Review, and was amazed at what he saw when visiting the laboratory. He reported that it could be a research department at any high-tech manufacturer; instead, the lab belonged to the government-funded Swedish Center for Working Life in Stockholm and he described the scene where graphic workers and computer scientists sat side by side as "an intriguing experiment in technology development" $[11,35]$.

One of the more important results was the publication of requirement specifications (kravspecifikationer) in 1983. The requirement specifications acted as guidelines for what workers should require of new technologies or organizations when introduced, and they were used in collective bargaining and local negotiations [36].

The UTOPIA-project presented its results at a conference in May 1984 at the Social Democratic Youth League's (Sveriges Socialdemokratiska Ungdomsförbund, SSU) residential study center Bommersvik [11, p. 259]. The choice of place symbolized and manifested the strong connections with the labor movement; during the latter half of the twentieth century, the Bommersvik residence was a political and cultural center for the Swedish labor movement.

Should the UTOPIA-project be evaluated as a success or as a failure? According to the researchers, the project led to "a successful conclusion" as a "single demonstration example." It demonstrated that alternative technological and organizational solutions for newspapers could be developed, which gave possibilities for graphic workers to improve their skills and keep their jobs. The participating researchers nurtured a dream that the project would contribute to a "new Scandinavian model" for technological development. However, as they later pointed out, the lack of trade union cooperation put an end to this dream [6, 11, p. 260]. Nevertheless, as a project on participatory design it must be considered seminal. It gave rise to the so-called Scandinavian School of System Development (Den skandinaviska skolan), where the users' participation in system development has become a key element [37]. Moreover, quite interestingly, an observer noted in 1990 that graphic workers in Sweden had managed to keep their occupations to a considerably higher extent than in the 
Anglo-Saxon countries [28]. To sum up, the counter-strategies against a computerbased wave of rationalization developed by the Nordic trade unions differed fundamentally from those articulated by trade unions in the Anglo-Saxon countries.

Acknowledgments. Handelsbankens forskningsstiftelser and Ridderstads stiftelse för historisk grafisk forskning have provided financial support for the research carried out in connection with this paper. Isabelle Dussauge, Johan Gribbe, Arne Kaijser, Anna Orrghen, Julia Peralta, Gustav Sjöblom, and Björn Thodenius have given valuable comments on earlier versions of this manuscript.

\section{References}

1. Magnusson, L.: Den tredje revolutionen - och den svenska arbetsmarknaden. Prisma, Stockholm (2000)

2. Wennersten, B.G.: Mikrodatoriseringen: Den tysta revolutionen: En guide för beslutsfattare. Affärsförlaget, Stockholm (1980)

3. Noble, D.F.: Progress without People: New Technology, Unemployment, and the Message of Resistance. Between the Lines, Toronto (1995)

4. Bix, A.S.: Inventing Ourselves Out of Jobs? America's Debate over Technological Unemployment, 1929-1981. Johns Hopkins University Press, Baltimore (2000)

5. Moore, R., Levie, H.: New Technology and the Trade Unions. Workers' Control (2), 13$21(1982)$

6. UTOPIA-projektet: Alternativ i text och bild. Graffiti (7) (1984)

7. Nygaard, K., Bergo, O.T.: Databehandling, planlegging og styring: Grunnbok for fagbevegelsen. Norsk regnesentral, Oslo (1972)

8. Braverman, H.: Labor and Monopoly Capital: The Degradation of Work in the Twentieth Century. Monthly Review Press, New York (1974)

9. Braverman, H.: Arbete och monopolkapital: Arbetets degradering i det tjugonde århundradet. Rabén \& Sjögren, Stockholm (1977)

10. Ehn, P., Perby, M.-L., Sandberg, Å.: Brytningstid: Teknik, arbete och facklig kamp i grafiska branschen: Rapport från samarbetet mellan Svenska Dagbladets Kamratklubb och Demos-projektet. Arbetslivscentrum, Stockholm (1983)

11. Bødker, S., et al.: A UTOPIAN Experience: On Design of Powerful Computer-Based Tools for Skilled Graphic Workers. In: Bjerknes, G., Ehn, P., Kyng, M. (eds.) Computers and Democracy: A Scandinavian Challenge, Avebury, Aldershot (1987)

12. Winner, L.: Autonomous Technology: Technics-Out-of-Control as a Theme in Political Thought. MIT Press, Cambridge (1977)

13. Edgerton, D.: Tilting at Paper Tigers. The British Journal for the History of Science 26(1), 67-75 (1993)

14. Smith, M.R.: Technological Determinism in American Culture. In: Smith, M.R., Marx, L. (eds.) Does Technology Drive History? The Dilemma of Technological Determinism. MIT Press, Cambridge (1994)

15. Tekniken och morgondagens samhälle. Tiden, Stockholm (1956)

16. Skovdahl, B.: Tingsten, totalitarismen och ideologierna. Symposion, Stockholm (1992)

17. Weinberger, H.: Nätverksentreprenören: En historia om teknisk forskning och industriellt utvecklingsarbete från den Malmska utredningen till Styrelsen för teknisk utveckling. KTH, Avd. för teknik- och vetenskapshistoria, Stockholm (1997) 
18. Att välja framtid: Ett underlag för diskussion och överväganden om framtidsstudier i Sverige: Betänkande. Statens offentliga utredningar (SOU), 1972:59, Stockholm (1972)

19. Isacson, M.: Arbetets organisation och ledning. In: Berggren, L., et al.: Det lyser en framtid: Svenska Metallindustriarbetareförbundet 1957-1981. IF Metall, Stockholm (2008)

20. Företagsdemokrati och data: Sammanfattning av LOs handlingsprogram. LO, Stockholm (1976)

21. Solidariskt medbestämmande: Rapport till LO-kongressen 1976: Med kongressens beslut. Prisma i samarbete med Landsorganisationen i Sverige, Stockholm (1976)

22. Birgitta Frejhagen, interview by Per Lundin (November 29, 2007)

23. Datoranvändning: Från samråd till medbestämmande. LO och Brevskolan, Stockholm (1978)

24. Datorer på människans villkor. ABF, Stockholm (1979)

25. Datorer på människans villkor: Program för datapolitiken. Socialdemokraterna, Stockholm (1979)

26. Datorerna och samhällsutvecklingen: Debattinlägg vid Tage Erlanders datasymposium 1980. Tiden, Stockholm (1980)

27. Johansson, A.: Taylorismen och arbetarrörelsen: En problemdiskussion. In: Schiller, B., Svensson, T. (eds.) Arbete och arbetsmarknad i Norden: Nya linjer inom den nordiska arbetslivsforskningen, Arkiv, Lund (1988)

28. Johansson, A.L.: Teknikoptimismen i den svenska modellen. In: Beckman, S. (ed.) Teknokrati, arbete, makt. Carlsson, Stockholm (1990)

29. Bjerknes, G., Ehn, P., Kyng, M. (eds.): Computers and Democracy: A Scandinavian Challenge. Avebury, Aldershot (1987)

30. Pedersen, U.S.: Fagbevægelsen og spørsmålet om industrielt demokrati i Skandinavien: Nogle problemstillinger og resultater fra et komparativt skandinavisk project. In: Schiller, B., Svensson, T. (eds.) Arbete och arbetsmarknad i Norden: Nya linjer inom den nordiska arbetslivsforskningen, Arkiv, Lund (1988)

31. Judt, T.: Postwar: A History of Europe since 1945. Heinemann, London (2005)

32. Johansson, J.: Arbetsmiljöfonden: Lagen om avsättning till arbetsmiljöfond. Tholin/Larsson-gruppen, Göteborg (1974)

33. The Swedish Center for Working Life, 1976-1987: ALC Review Committee. Arbetslivscentrum, Stockholm (1987)

34. Sandberg, Å. (ed.): Arbete, ledning och teknik: Resultat från ett forskningsprogram om omvandling i företag och fack vid Arbetslivscentrum 1975-1991. Arbetslivscentrum, Stockholm (1991)

35. Howard, R.: UTOPIA: Where Workers Craft New Technology. Technology Review 88(3), 43-49 (1985)

36. Kravspecifikation - teknik, arbete och utbildning. Graffiti (7), 24-25 (1984)

37. Asp, M., James, S.: Trender inom skandinavisk systemutveckling. Unpublished report, MSI, Växjö universitet (June 2003) 